\title{
Anthropologists split over misconduct claims
}

\section{Rex Dalton, San Diego}

One year after a journalist rocked the world of anthropology with allegations of serious misconduct in research among Amazonian tribes, the American Anthropological Association (AAA) remains deeply divided over how to respond. In the latest twist, the society has been forced to remove a draft report on the allegations from its website, following dissent among contributors over its contents.

In his book Darkness in El Dorado: How Scientists and Journalists Devastated the Amazon, Patrick Tierney examined three decades

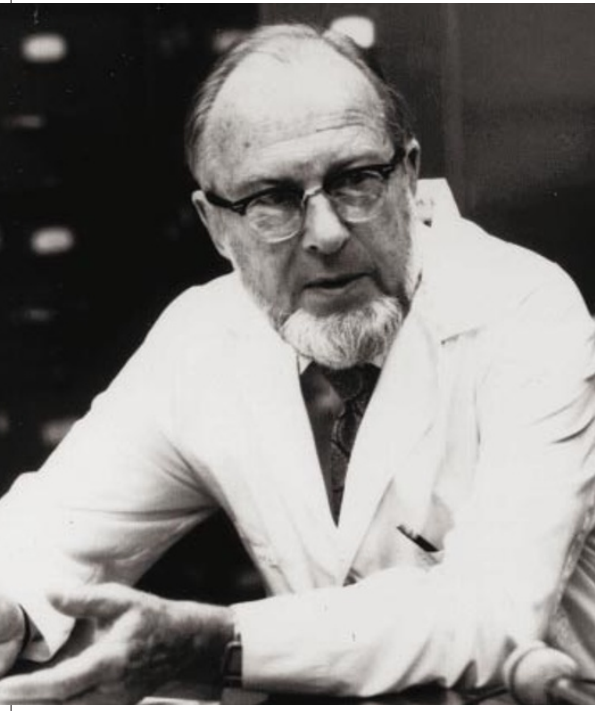

James Neel (above) is accused of improper research into the Amazonian Yanomami people. of research among the Yanomami people in Venezuela. He alleged that geneticist James Neel of the University of Michigan and anthropologist Napoleon Chagnon of the University of California, Santa Barbara, improperly bartered weapons for interviews, conducted clinical studies without informed consent, and may have exposed the Yanomami to infectious diseases (see Nature 408, $391 ; 2000$ ). Neel died in 2000 before the book was published, but Chagnon, who is retired, has protested his innocence.

The AAA subsequently set up a task force

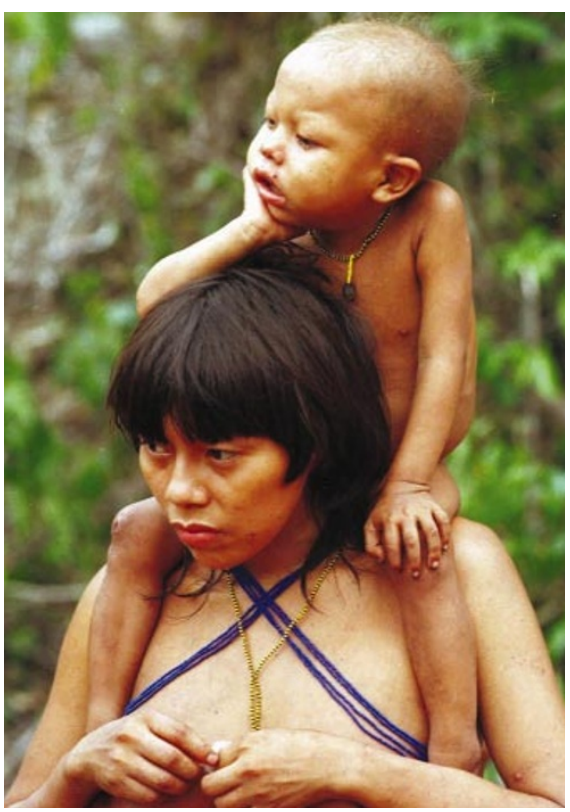

to investigate the charges and to draw up new standards for the conduct of studies of indigenous peoples. An early draft appeared on the society's website shortly before the AAA's annual meeting in Washington in November. But at that gathering, the society's leaders were heavily criticized over the draft's contents, and for making it available. It was removed from the website shortly afterwards.

At the meeting, Fernando Coronil of the University of Michigan and Janet Chernela of Florida International University near Miami, both members of the task force, complained that they had not seen the document before it was put online. Both argued that the draft failed to accurately reflect the accused researchers' responsibility for identified problems.

The disagreements show how hard it is for scientific societies to deal with allegations of misconduct, particularly when the accused — like Neel and Chagnon - are prominent figures. Jane Hill of the University of Arizona in Tucson, who chairs the task force, says that there is still much work to do. AAA officials hope that the task force will nonetheless complete its report by the spring.

At the AAA meeting, Coronil won support for a proposal allowing members to write and sign individual sections of the report. This, he hoped, would allow the task force "to make a more powerful statement". But whether it will lead to a report that is acceptable to both the task force and the association's members remains unclear.

www.aaanet.org

\section{Museum staff strike to prevent loss of artefacts}

Many of the staff at France's leading anthropology museum, the Musée de l'Homme in Paris, are on strike in protest at a proposal to move its ethnology collection to a new museum of primitive art and civilizations.

The staff are angry that they may be deprived of access to the artefacts, which represent peoples from around the world. "Without our collections, we can no longer function as a museum, linking teaching and research," claims Bernadette Robbe, a researcher at the museum's ethnology laboratory, and a member of the strike committee.

The backdrop to the strike is a widely accepted need to reform the museum, which has failed to modernize the presentation of its collections and has slipped back from the forefront of anthropological research. After much debate, a commission set up by French president Jacques Chirac decided to transfer the ethnology collection, the museum's library and its photographic collections, to a new museum, due to open in 2004. This will be known as the Musée du quai Branly, after its riverside location in the east of Paris.

But Robbe argues that no decisions about the collections should have been taken without consultation with the new president and scientific advisory committee of the National Natural History Museum - the Musée de l'Homme's parent body. As Nature went to press, appointments to these posts had not been made, but were expected imminently. Robbe accepts that the museum needs to be reformed, but says that lack of money and personnel have prevented staff from taking their ideas forward.

Jean-Claude Moreno, the interim administrator of the natural history museum, says that the strike is symptomatic of the museum's "intellectual and scientific crisis". He argues that the museum has missed at least three opportunities to reform its research programme, because staff could not agree on a coherent scientific project.

The decision to move the collections has provoked mixed responses in the wider research community. William Sturtevant, curator of North American ethnology at the Smithsonian Institution's National Museum of Natural History in Washington, describes the collections as among the best half-dozen in the world. "The proposed change is potentially disastrous for preservation of and access to the artefacts," he says.

But Dominique Michelet, deputy director of the unit of Archaeology of the Americas in Paris, part of the CNRS, France's national research agency, says: "This is an unmissable opportunity to restore the collections and recreate a strong research base."

www.mnhn.fr/mnhn/mdh

www.quaibranly.fr/00/dynamique/home.htm/an 